\title{
OBITUARIES
}

\section{Prof. Pierre Bugnon}

Pierre Frédéric Bugnon was born on January 14, 1886, and died on May 11, 1957. After holding academic posts at Caen and Rennes, he was, until his retirement, professor of botany at Dijon. In his student days he worked at botany, zoology and geology at the Universities of Caen and Lyons. In 1910 and 1911 he was Octave Lignier's pupil, and he later became his colleague at Caen. Lignier's mind had more than a touch of genius, and his intellect and insight were the determining factors in the primary orientation of Bugnon's researches. Lignier recommended him to make himself proficient in the morphology and anatomy of modern plants before turming to the problems of fossil botany, and it was, in the end, the structure and phylogeny of the plants of to-day to which Bugnon gave his allegiance, though he retained his interest in palæobotany.

Bugnon obtained his Paris doctorate in 1921 for a thesis on the leaf in the Gramineae, in which he gave special attention to the phylogenetic evidence derived from the peculiar seedling structure of this group. He developed different aspects of his thesis in the succeeding years, his memoir on the ontogeny of the conducting system in the Gramineae being specially notable. Eventually his work branched out from these and related topics to studies of many other problems arising out of the morphology of the flowering plants. In a brief note such as this, no adequate idea can be given of the scope and variety of his own large output, or of the work of the research students whom he directed and inspired. He often dealt, lucidly and incisively, with controversial questions; even when one disagreed with his interpretations, his memoirs were always found to be thoughtful and thought-provoking. $\mathrm{He}$ had the French capacity for absorption in the things of the mind, controlled always by a deep respect for the facts of experience. His standards were high, and he was entirely without pretension; he once said to me, "Je suis barbare, moi", but this description of himself was belied completely by his own sensitive verbal expression, and by his horror at those misuses of language in which quiet appropriateness is lost through over-emphasis.

Though they were merely side-issues among Bugnon's preoccupations, his enthusiastic contributions to the field botany of Normandy deserve mention. Late in August, 1927, my daughter and I spent an unforgettable day walking under his guidance in the region of the joint estuary of the Douve and the Vire to see the cord-grass fields. We were accompanied by Louis Corbière, who had detected Spartina townsendii here for the first time in 1906, when 15-20 tufts were observed in one place, and another small stand elsewhere. Twenty-one years later, when we saw it during this walk in the full beauty of its anthesis, it had succeeded in clothing some two thousand acres of what had formerly been sterile mud flats.

Pierre Bugnon's son, François, known for his work on morphology and anatomy, began his botanical career in his father's laboratory, and thus, indirectly, under Lignier's influence. A research tradition of quality and individuality, which might have been extinguished by Lignier's premature death, has thus been transmitted to further generations of botanists through Pierre and François Bugnon and their students. AGNES ARBER

\section{Dr. H. R. Heath}

Dr. H. R. Heath, head of the Physics Department of Battersea Polytechnic, died at the early age of forty-two on May 4, after a painful illness. Educated at Halesowen Grammar School, he proceeded to the University of Birmingham, took an honours degree in physies, and was later awarded the Ph.D. degree for his research work on diffusion.

Dr. Heath had been a member of the physies lecturing staff of Battersea Polytechnic since the autumn of 1939, except for a break of four years war service in the R.A.F. Soon after his return to teaching, he was appointed senior lecturer in physics, and four yoars later became head of the Department. In the comparatively short time that he was to hold this office, Dr. Heath had been concerned with the building expansion of the Physics Department and with the initiation of a number of fresh courses in preparation for the new diploma in technology. Although taking his full share in teaching and in university examining work, he was also very active in extending the research activities in his Department.

Most conscientious in everything he undertook and always deeply concerned with the well-being of his students, his passing is a tragic loss at a time when he had still so much to contribute. Dr. Heath leaves a widow and a fifteen-year old son.

R. W. B. Stephens

\section{Sir William Beach Thomas, K.B.E.}

FEW writers on the English countryside knew their subject better than the late Sir William Beach Thomas, who died on May 12. An athlete in his younger days - he was president of the Oxford University Athletic Club-a sometime war correspondent of distinction and a man of many activities, it is nevertheless his writings on country-life and Nature that constitute his outstanding achievement. A regular contributor to the Observer and the Spectator over many years and the author of a number of books, his love of the 'coloured counties' blazes from every article and every volume. He was a naturalist in the tradition of Gilbert White and Lord Gray, with an intense love for, and an unappeasable interest in, the life of field and hedgerow, coppice, stream and hillside, to say nothing of village and farmstead.

The son of a country clergyman, educated at Shrewsbury and Oxford, he was buth by origin and upbringing a countryman, an Englishman who let his love of the countryside flow down his pen and on to paper with a fluency and skill that few have equalled, even if it was not always easy to decipher his handwriting. His books are truly English and full of the sights and sounds, the scents and smells, that from dawn to dusk and from sundown to sunrise make our England.
Frances PtTT 